\title{
Úton a függetlenség felé?
}

\section{Törökország földgázpolitikájának (át)alakulása egy változó energiabiztonsági architektúrában}

\begin{abstract}
Jelen tanulmány a Törökország földgázbeszerzéseit befolyásoló körülményekben végbement változásokat és azok geopolitikai összefüggéseit vizsgálja az elmúlt évek vonatkozásában. Az elemzés arra világít rá, hogy Törökország helyzete a régió energiabiztonsági folyamataiban jelentős átalakuláson ment és megy keresztül napjainkban is, a korábbiakhoz képest Ankara immáron jobb infrastrukturális feltételekkel és fejlődő alkupozíciókkal rendelkezik az ország földgázbeszerzéseinek szervezése terén, ugyanakkor az ország energiapolitika-orientált külpolitikája korántsem mentes a feszültségektöl, ami különösképpen a Földközi-tenger keleti medencéjében vált láthatóvá.
\end{abstract}

Kulcsszavak: Törökország, földgáz, Kelet-Mediterráneum, Fekete-tenger, Oroszország

\section{On the Way to Independence?}

The Changes of Turkey's Natural Gas Policy in a changing energy security architecture

This paper assesses the changes that have taken place in recent years in the circumstances affecting Turkey's natural gas purchases, as well as their geopolitical implications. The analysis highlights that Turkey's situation in the region's energy security processes has undergone a transformation and continues to do so these days, with Ankara now having better infrastructural conditions and improving its bargaining position in organising the country's natural gas purchases. At the same time, the country's energy policy oriented foreign policy is by far free from tensions which have become particularly visible in the Eastern Mediterranean.

Keywords: Turkey, natural gas, Eastern Mediterranean, Black Sea, Russia

\section{Bevezetés}

A 2020-as év sok szempontból mozgalmas volt Törökország számára: aktívan beavatkozott a líbiai konfliktusba, utat nyitott egy rövid ideig tartó, ugyanakkor annál látványosabb me-

Kozma Tamás az Antall József Tudásközpont Ázsiai és Afrikai Kapcsolatok Irodájának vezetője. E-mail: kozma.tamas@ ajtk.hu

2 Egeresi Zoltán a Nemzeti Közszolgálati Egyetem Eötvös József Kutatóközpont Stratégiai Védelmi Kutatóintézet tudományos segédmunkatársa. E-mail: egeresi.zoltan@uni-nke.hu 
nekültválságnak, ${ }^{3}$ miközben egy sikeresnek kikiáltott szíriai offenzívában megvédte a déli szomszéd északi részén lévő érdekeltségeit. Az egyre asszertívebbé váló török külpolitika hadihajók küldésével demonstrálta területi igényeit a Földközi-tenger keleti medencéjében, illetve katonai segítsége kulcsfontosságúnak bizonyult a szeptember végétől november elejéig zajló második karabahi háborúban az azeriek sikerében, aminek köszönhetően Törökország növelte befolyását a Dél-Kaukázusban.

A látványos külpolitikai manőverek mögött szinte észrevétlen maradt a török gázkereskedelem átalakulása, amely ebben az évben jelentős eredményeket mutathatott fel az orosz gázfüggőség erőteljes csökkentésével, ami Ankara mozgásterét is megnövelte Moszkvával szemben. A tanulmány célja, hogy megvizsgálja, hogyan változott az utóbbi években a török gázkereskedelem, milyen tényezők játszottak közre ebben, illetve a regionális energiaelosztó szerepre való törekvés hogyan befolyásolja az ország külpolitikáját.

Az elemzés első része a török energiaszektort mutatja be, különös tekintettel a gázimport szerepére, majd a 2020-as év fordulatait veszi górcső alá, így a különböző feltárásokat és infrastrukturális fejlesztéseket. A következö, nagyobb részben a gázimport átalakulását és a partnerdiverzifikációra tett erőfeszítéseket vázolja föl. Végezetül az ország energiaelosztó szerepre tett törekvéseit elemzi a tanulmány, így azt a folyamatot, hogy miként válik az ország tranzitországgá. Továbbá pedig azt, hogy hogyan lép fel a környező régióban, elsődlegesen a Kelet-Mediterráneumban, hogy akadályozza a gázkitermelést.

\section{Az energiaügyek felértékelődése Törökország számára}

Törökország lakossága az 1999 és 2019 között eltelt két évtizedben 62,3 millió forről 83,4 millió főre, míg az ország bruttó hazai összterméke 255,9 milliárd dollárról 754,4 milliárd dollárra emelkedett. ${ }^{4}$ A népesség számottevő növekedésének, valamint a gazdaság dinamikus fejlődésének eredményeként jelentős mértékben megnövekedett az ország energiaszükséglete is, amelynek kielégítésében fokozatosan növekvő szerephez jutott a külföldről beszerzett földgáz. Míg 1999-ben mindössze 13 milliárd köbméterre, 2019-re már 44,9 milliárd köbméterre volt tehető Törökország földgázszükséglete, megjegyezve, hogy a csúcsát 2017-ben érte el: ekkor 53,6 milliárd köbméter volt az ország földgázigénye. ${ }^{5}$ Mivel Törökország földgázellátása 99\%-ban importon alapszik, ezért az ország gázigényének növekedése, és így a gázimport kényszerü gyarapodása erős importfüggőségi viszonyok kialakulásához vezetett.

Egeresi Zoltán - Kacziba Péter: Menekültválság a görög-török határon: Előzmények, fejlemények, kilátások. [online], KKI Elemzések, (2020), 25. 1-15. Forrás: [2020. 12. 14.]

4 The World Bank: Turkey - Dataset. [online], 2020. Forrás: data.worldbank.org [2020. 12. 16.]; Érdemes megjegyezni, hogy Törökország bruttó hazai összterméke a Világbank statisztikái alapján 2013-ban érte el csúcspontját: akkor meghaladta a 950 milliárd USD értéket, az azóta eltelt időszakban viszont csökkenő tendenciát mutat.

Organization of the Petroleum Exporting Countries: Annual Statistical Bulletin. [online], 2020. Forrás: opec.org [2020. 12. 16.] 


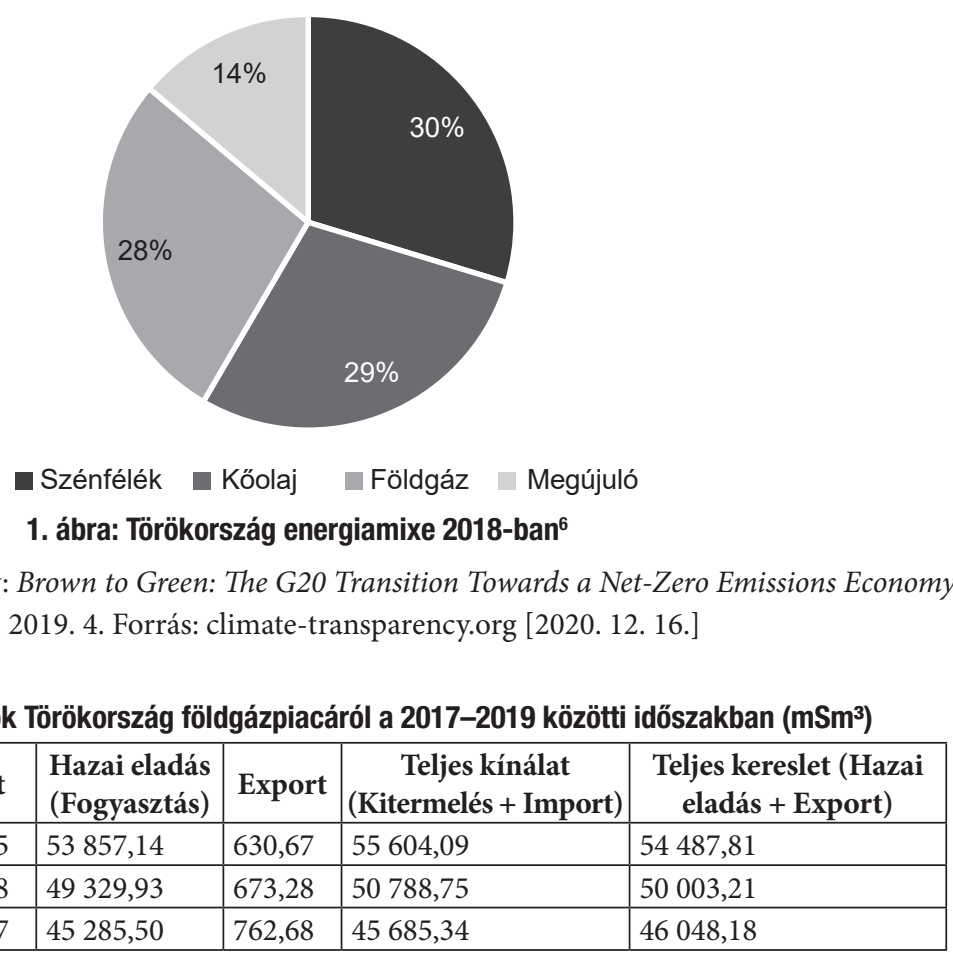

1. táblázat: Kulcsadatok Törökország földgázpiacáról a 2017-2019 közötti időszakban ( $\mathrm{mSm}^{3}$ )

\begin{tabular}{|l|l|l|l|l|l|l|}
\hline & Kitermelés & Import & $\begin{array}{c}\text { Hazai eladás } \\
\text { (Fogyasztás) }\end{array}$ & Export & $\begin{array}{c}\text { Teljes kínálat } \\
\text { (Kitermelés + Import) }\end{array}$ & $\begin{array}{c}\text { Teljes kereslet (Hazai } \\
\text { eladás + Export) }\end{array}$ \\
\hline 2017 & 354,14 & 55249,95 & 53857,14 & 630,67 & 55604,09 & 54487,81 \\
\hline 2018 & 428,17 & 50360,58 & 49329,93 & 673,28 & 50788,75 & 50003,21 \\
\hline 2019 & 473,87 & 45211,47 & 45285,50 & 762,68 & 45685,34 & 46048,18 \\
\hline
\end{tabular}

Forrás: T.C. Enerji Piyasası Düzenleme Kurumu: Doğal Gaz Piyasası 2017-2018-2019 Yılı Sektör Raporu. [online], Forrás: epdk.gov.tr [2020. 12. 16.]

Az ország gázellátásának szervezése a fentiek értelmében jelentősen túlmutat az energiagazdálkodási kérdéseken, így azt ma egy, a külpolitikai tényezőket is figyelembe vevő, geopolitikai-geoökonómiai narratívában szükséges vizsgálnunk. Érthető tehát, hogy az energiapolitikai megfontolások és törekvések mára a török külpolitika elidegeníthetetlen részévé váltak, és különös figyelem összpontosul a földgáz helyzetére, amely nemcsak Törökország, hanem Európa és az Európai Unió, sőt az egész transzatlanti közösség nézőpontjából is egy meglehetősen átpolitizált energiahordozóvá vált. ${ }^{7}$ Ezzel együtt a nemzetközi kapcsolatokkal foglalkozó kutatók figyelme is egyre inkább Törökország energiabiztonság-orientált külpolitikai folyamataira irányult, és számos török és külföldi szerzö - köztük több magyar elemző is - foglalkozik a Törökország földgázszektorát érintő események és azok tágabb külpolitikai összefüggéseinek kutatásával. ${ }^{8}$

\footnotetext{
A megjelölt forrásban megadott értékek a kerekítésekből fakadóan összesen 1\%-os eltéréshez vezetnek.

Lásd pl.: Rem Korteweg: Energy as a tool of foreign policy of authoritarian states, in particular Russia. [online], 2018. Forrás: European Parliament [2020. 12. 17.]

8 Törökországi szerzők közül lásd például Mitat Çelikpala, Eser Özdil, Okan Yardımcı vagy Oktay Tanrısever munkáit. Külföldi szerzők közül kiemelhetők többek között Gulmira Rzayeva, Simone Tagliapietra, Brenda Shaffer vagy Dimitar Bechev írásai. Magyarországi szerzők közül lásd Egeresi Zoltán, Kacziba Péter, Kozma Tamás, Pénzváltó Nikolett vagy Tongori Zsófia munkáit.
} 
Noha számos narratívából közelíthetjük Törökország földgázpolitikáját, a következő négy célkitüzésen alapuló szempontrendszer mindenképpen segíti Ankara motivációinak felvázolását.

1. Törökország, mint lényegében teljes mértékben gázimportfüggő ország, elsődleges célja, hogy biztosítsa hazai gázszükségletének ellátását.

2. Másrészt célkitüzése, hogy földgázimport-struktúráját folyamatosan diverzifikálja, rugalmasabbá tegye, és kiegyensúlyozza Oroszország az 1990-es és 2000-es években kialakult domináns szerepét az ország gázellátásában.

3. Harmadrészt, Törökország célja, hogy erősítse az ország beágyazottságát a régió energiabiztonsági architektúrájában azáltal, hogy fejleszti gáztranzitképességeit, és infrastruktúráját abból a célból, hogy az országból egy kulcsfontosságú energiaszállítási útvonal, sőt regionális gázkereskedelmi csomópont, úgynevezett „hub” válhasson.

4. Negyedrészt, az előző három kérdésben elért eredményeit Ankara összességében is a külpolitikai mozgásterének bővítésére, regionális hatalmi pozíciójának erősítésére kívánja használni, ami az átalakulóban lévő közel-keleti erőviszonyok között különösen relevánssá vált.

\section{Aktualitások 2020-ban}

2020-ban számos olyan esemény és folyamat ment végbe Törökország földgázügyi pozícióinak vonatkozásában, amelyek figyelmet érdemelnek, megjegyezve, hogy ezek egy, a megelőző éveken át folytatólagosan követett energiapolitikai kurzus eredményei, következményei. Elsőként fontos megemlíteni, hogy 2020 januárjában adták át az Oroszországot Törökországgal közvetlenül, a Fekete-tengeren keresztül összekötő, 15,75 milliárd köbméteres évenkénti szállítási kapacitású Török Áramlat gázvezetékprojekt első vezetékét, amely így a Kék Áramlat mellett immáron a második közvetlen orosz-török gázvezetékként szolgálja a török piac ellátását, amellett, hogy lehetővé teszi Oroszország számára, hogy tovább csökkentse az Ukrajnán keresztül történő gázexportját. ${ }^{9}$ A Török Áramlat ugyanis kiváltani hivatott az Ukrajnán és a Balkánon keresztülhaladó „Nyugati Útvonal” vagy máskor „Transzbalkánként” hivatkozott vezetéket, amely tradicionálisan a Balkánra és Törökországba irányuló orosz gázexport útvonala volt. Szintén megemlítendő, hogy az Európai Unió is támogatja a balkáni gázimporthoz kapcsolódó infrastruktúra kiépítését. Ebben ráadásul az Azerbajdzsánból érkező, Törökországon áthaladó TANAP-TAP gázvezeték kaphat fontos szerepet. ${ }^{10}$

Szükséges rávilágítani, hogy július-augusztusban ismételten kiújultak a feszültségek Törökország és Görögország között, Törökországnak a Földközi-tenger keleti medencéjének vitatott hovatartozású területein folytatott energetikai célú kutatásai miatt,

9 Euractiv: Turkey, Russia launch Turkish Stream pipeline carrying gas to Europe. [online], 2020. 01. 09. Forrás: euractive. com [2020. 12. 16.]

10 Deák András György: Alternatíva, potyautas vagy hajótörött - a földgáz esélyei Délkelet-Európában. [online], Stratégiai Védelmi Kutatóintézet Elemzések, (2020), 26. 1-15. Forrás: mhtt.eu [2020. 12. 16.] 
amely elhúzódó konfliktushelyzetet eredményezett. ${ }^{11}$ Szintén augusztusban jelentette be Törökország, hogy 320 milliárd köbméter becsült készlettel rendelkező földgázmezőt talált a Fekete-tenger alatt a török Különleges Gazdasági Övezetben (EEZ), ${ }^{12}$ majd a becslést október hónap folyamán 405 milliárd köbméterre pontosították. ${ }^{13}$ Emellett októberben számos sajtóorgánum beszámolt arról is, hogy 2021-re várható, hogy átadják az ország harmadik úszó gáztároló és regazifikációs terminálját (floating storage and regasification unit - FSRU), ami újabb elörelépés az ország energiabiztonsági infrastruktúrájának ${ }^{14}$ fejlesztésében. ${ }^{15}$ Mindemellett, 2020-ban látható módon elötérbe került Törökország évek óta zajló gázdiverzifikációs törekvéseinek eredménye: az ország gázellátásában mind hangsúlyosabban jelentek meg a cseppfolyósított gázszállítások (liquefied natural gas - LNG), amelyeket különösen fontos annak tükrében vizsgálni, hogy ez milyen hatással van Oroszország pozíciójára Törökország gázellátásában. Utóbbi azért is különösen időszerű kérdés, mivel az elkövetkezendő években Törökország számos hosszú távú gázvásárlási szerződése jár le, többek között az orosz Gazprommal, így tehát a korábban rendkívül stabil orosz-török földgázdinamikák terén is szükséges értékelni az elmúlt időszak eseményeit.

\section{Törökország földgázimportjának (át)alakulása}

Törökország földgázellátásának gerincét hagyományosan az Oroszországtól, Irántól és Azerbajdzsántól vásárolt vezetékes földgáz, valamint az Algériától és Nigériától vásárolt cseppfolyósított földgáz adja, amely szállításokat kisebb mértékben egészítenek ki az azonnali piacokon beszerzett LNG-mennyiségek. Törökország a földgázbeszerzéseinek vonatkozásában a legnagyobb mértékben mindig is Oroszországtól függött: 2011-ben az ország teljes gázimportjának 57,9\%-a, 2015-ben 55,3\%-a, míg 2019-ben viszont már csak 33,6\%-a származott innen. ${ }^{16}$ A Törökország gázbeszerzéseinek diverzifikációjára irányuló törekvések hosszú idő óta jelen voltak a török energiapolitikai gondolkodásban, de ezek eredményei 2016-2018-tól kezdve váltak csak láthatóvá, köszönhetően annak, hogy ebben az időszakban helyeztek üzembe újabb két törökországi LNG-terminált, valamint az azerbajdzsáni eredetű földgázt szállító TANAP-vezetéket is, amely infrastruktúrák segítségével Törökország számára új perspektívák nyíltak meg a gázbeszerzéseinek kiegyensúlyozottabbá tételére. A 2. ábrából és a 2., 4. számú táblázatokból

11 Sinem Adar - Ilke Toygür: Turkey, the EU and the Eastern Mediterranean Crisis: Militarization of Foreign Policy and Power Rivalry. [online], Stiftung Wissenschaft und Politik Comment, (2020), 62. 1-4. Forrás: swp-berlin.org [2020. 12. 16.]

12 David O’Byrne: Turkish President Erdogan announces 320 Bcm Black Sea gas discovery. [online], 2020. 08. 21. Forrás: spglobal.com [2020. 12. 16.]

13 David O’BYRNE: Turkey increases size of Black Sea gas find by 85 Bcmto 405 Bcm. [online], 2020. 10. 17. Forrás: SPGlobal.com [2020. 12. 16.]

14 A két már létező FSRU-ból az egyik Izmir mellett, Aliağaban (2016) található, míg a másik İskenderunban (2019). Ezeken kívül két szárazföldi LNG-létesítmény is van, az egyik Rodostó közelében Mermara Ereğlisiben (1994), a másik pedig szintén Aliağanban (2006).

15 Hürriyet Daily News: Turkey to expand LNG storage capacity with 3rd FSRU. [online], 2020. 10. 09. Forrás: hurriyetdailynews.com [2020. 12. 16.]

16 T.C. Enerji Piyasası Düzenleme Kurumu: Doğal Gaz Piyasası 2019 Yılı Sektör Raporu. [online], 2020. 10. Forrás: epdk. gov.tr [2020. 12. 16.] 
együttesen kiolvasható trendek rávilágítanak, hogy Oroszország korábbi vezető pozíciója Törökország gázellátásában nem elhanyagolható mértékben megingott, ez a tendencia 2020. II. negyedévében pedig különösképpen kicsúcsosodott. Noha jelen cikk írásakor még nem állnak rendelkezésre a 2020 -as évre vonatkozó összesített adatok, a táblázatokból kiolvasható, hogy 2020-ban mélypontra zuhant Oroszország piaci részesedése a török gázpiacon, és ezzel párhuzamosan korábban nem látott mértékü fejlődés ment végbe Azerbajdzsán piaci részesedésében és az LNG-beszerzések terén is. Az Oroszországból importált gázmennyiség visszaesésének okai között említhetjük a gáz iránti kereslet csökkenését, amely a 2020-as év vonatkozásában nem tehetö függetlenné a Covid-19-járvány gazdasági hatásaitól: Törökország energiaigénye 4,5\%-kal csökkent az év első öt hónapjában, az ipari szektor gázfogyasztása $16 \%$-kal, míg a lakossági szektoré $2 \%$-kal csökkent. ${ }^{17}$ Szintén drasztikusan, a nullára esett vissza az iráni gázkereskedelem, ami az iráni-török gázvezetékben márciusban történt robbanás miatt következett be - a szállítás csak három hónap múlva indult újra. ${ }^{18}$ Mindazonáltal Irán Oroszország és az LNG-beszállítók mellett fontos partner marad, noha Törökországnak már többször okozott gondot a magas iráni gázár (ez ügyben nemzetközi bírósághoz is fordult, amit megnyert) ${ }^{19}$ vagy a gázszállítások elmaradása.

A pandémia hatása 2020-ban meghatározó, ugyanakkor a csökkenő tendencia az orosz gázt illetően már a korábbi években elkezdődött. A közeljövőben mindenesetre várhatóan a járvány velünk fog maradni. Az orosz gáz háttérbe szorulásának további okai között említhetjük még a hosszú távú gázvásárlási szerződéseken alapuló kedvezőtlen gázárakat, és az ehhez képest olcsóbb LNG vásárlásának a lehetőségét. Ugyanakkor szükséges felhívni a figyelmet arra is, hogy 2020 júliusától kezdve ismét több gázt vásárol Törökország a Gazpromtól, mivel egyfelől a gáz iránti kereslet is megnövekedett, másfelöl pedig a Gazprom által kínált gáz ára is csökkenésnek indult, ami mutatja, hogy az LNG-csöves gázszállítás között egy létező árverseny van, amely a török vásárlásokra is kihat, még akkor is, ha a diverzifikáció mint célkitüzés alakítja a gazdaságpolitikát. ${ }^{20}$

2020 augusztusa más szempontból is fontos momentumnak tekinthető Törökország számára: ekkor jelentették be, hogy 320 milliárd köbméteres gázmezőt (Sakarya mező) találtak a Fekete-tengerben, októberben pedig a pontosítást tették közzé, így ekkor már 405 milliárd köbméteres felfedezésről szóltak a hírek. ${ }^{21}$ Mindez fontos fordulópontnak tekinthető, hiszen bizonyos szempontból ez a felfedezés kompenzálni tudja Törökország

17 Gulmira Rzayeva: The Renewal of Turkey's Long Term Contracts: Natural gas market transition or 'business asusual'? [online], 2020. 09. 1. Forrás: oxfordenergy.org [2020. 12. 16.]

18 Aresu Eqbali - David O'Byrne: Iran expects gas flows to Turkey to resume in July, rejects force majeure claim. [online], 2020. 07. 08. Forrás: spglobal.com [2020. 12. 16.]

19 Hürriyet Daily News: Turkey wins gas price row against Iran in court. [online], 2016. 02. 02. Forrás: hurriyetdailynews. com [2020. 12. 16.]

20 The Oxford Institute for Energy Studies: Analysis of cross-border flows in SE Europe. [online], 2020. 12. 2-3. Forrás: oxfordenergy.org [2020. 12. 16.]

21 David O'Byrne: Turkey increases size of Black Sea gasfind by $85 \mathrm{Bcm}$ to $405 \mathrm{Bcm}$. [online], 2020. 10. 17. Forrás: spglobal. com [2020. 12. 16.] 
eddig sikertelen kutatásait a Földközi-tengerben, és erősítheti Törökország alkupozícióit a jelenlegi szállítóival szemben. Fontos megjegyezni, hogy az itt talált gázmennyiség noha számottevő, de gyors és drasztikus változásokhoz nem fog vezetni Törökország gázellátásában. ${ }^{22}$ A rendkívül optimista politikai kommunikáció szerint a Török Köztársaság kikiáltásának 100 éves évfordulójával azonos évben, tehát 2023-ban kezdődhet meg az itt talált gázkincs kitermelése, amelynek segítségével Törökország fokozatosan, de tovább fogja tudni folytatni gázellátásának diverzifikációját, és egyúttal csökkenteni gázimportszámláját. A megalapozottabb vélemények szerint viszont kitermelésre inkább a 2020-as évek vége felé számíthatunk. Hozzá kell tenni, hogy a 100\%-ban a nemzeti olajvállalat, a TPAO tulajdonában lévő Sakarya gázmező kitermelését elősegítő tényezőként azonosítható a politikai akarat, amely vélhetően kedvezően fogja befolyásolni a hatósági és szabályozási eljárásokat, ezzel is előmozdítva Törökország részleges önellátás felé történő elmozdulását. Ugyanakkor a projekt megvalósítását olyan kihívások is érik, mint például a tengerfenék mélysége (a Fekete-tenger kifejezetten mély részén található a mező, amelynek kitermeléséhez a török vállalatnak nincs meg a megfelelö technikája, így vélhetően partnereket kell bevonnia), a jelenben elérhetö alacsony gázárak, valamint a tény, hogy a kitermelés müszaki-infrastrukturális feltételeit nulláról kezdve kell megvalósítani. ${ }^{23}$

Törökország gázimportjainak átstrukturálódásával kapcsolatban szükséges felhívni a figyelmet arra is, hogy a 2020-as évtizedben Törökország lényegében minden hosszú távú gázvásárlási szerződése le fog járni. Csak 2021-ben 16 milliárd köbméternyi gázra szóló hosszú távú szerződés fog lejárni, amelyből 8 milliárd köbméter a Gazpromtól származó gázvásárlásait érinti. Törökország hosszú távú szerződéseinek küszöbön álló újratárgyalásának vonatkozásában több tényezőre is fontos rávilágítani. Törökország érdeke, hogy elmozduljon a rugalmatlan, olajárindexált hosszú távú gázvásárlási szerződésektől, a szerződésekben foglalt „vidd vagy fizess” (take or pay) kötelezettségektől, valamint az úgynevezett desztinációs klauzuláktól, amelyek az importált gáz továbbértékesítését hivatottak limitálni. ${ }^{24}$ Ezzel összhangban a török energiapolitika célja, hogy rugalmasabb, versenyképesebb legyen, és felhasználóbarát szerződésekkel biztosítsa gázvásárlásait, amelyek nem fogják a jelenlegihez hasonló módon megakadályozni abban, hogy valóban profitálni tudjon a világpiacon elérhető alacsony gázárakból, hogy ki tudja használni a kibővített LNG-infrastruktúrájában rejlő lehetőségeket, és hogy lépéseket tegyen azon stratégiai célkitüzés felé, hogy egy energiakereskedelmi csomópont váljon Törökországból. Utóbbi célkitűzésekhez azonban a külső partnerekkel történő tárgyalásokon kívül az is fontos lépcső, hogy a török gázpiac késlekedő liberalizációs folyamatában is elörelépések történjenek. ${ }^{25}$

22 Kacziba Péter: Törökország Fekete-tengeri gázfeltárásai - Lehetőségek, korlátok és regionális vonatkozások. Pólusok, 1. (2020), 1. 176-192.

23 Adrienne Cheasty: Black Sea gas: Economic and geopolitical implications. [online], 2020. 11. 16. Forrás: seesoxblog. blogspot.com [2020. 12. 16.]

24 Rzayeva (2020) i. m. 1.

25 Rzayeva (2020) i. m. 26-27. 


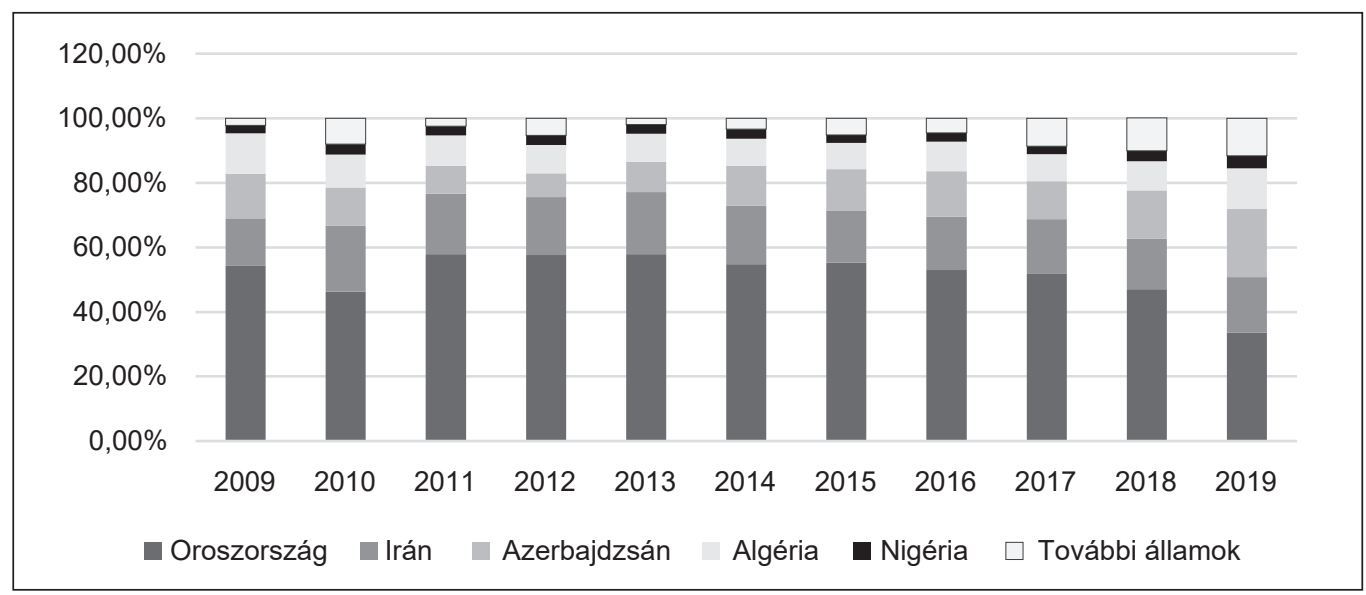

2. ábra: Törökország földgázimportjának megoszlása forrásországok szerint a 2009-2019 közötti időszakban

Forrás: T.C. Enerji Piyasası Düzenleme Kurumu: Doğal Gaz Piyasası 2019 Yılı Sektör Raporu. [online], 2020. 10. Forrás: epdk.gov.tr [2020. 12. 16.]

\section{2. táblázat: Törökország földgázimport-szerkezetének alakulása 2018-2020 májusa között}

\begin{tabular}{|l|c|c|c|c|c|c|}
\hline & \multicolumn{2}{|c|}{ 2018. május } & \multicolumn{2}{c|}{ 2019. május } & \multicolumn{2}{c|}{ 2020. május } \\
\cline { 2 - 7 } & $\begin{array}{c}\text { Mennyiség } \\
\left(\mathbf{m S m}^{\mathbf{3}} \mathbf{)}\right.\end{array}$ & $\begin{array}{c}\text { Részarány } \\
\mathbf{( \% )}\end{array}$ & $\begin{array}{c}\text { Mennyiség } \\
\left(\mathbf{m S m}^{\mathbf{3}}\right)\end{array}$ & $\begin{array}{c}\text { Részarány } \\
\mathbf{( \% )}\end{array}$ & $\begin{array}{c}\text { Mennyiség } \\
\left(\mathbf{m S m}^{\mathbf{3}}\right)\end{array}$ & $\begin{array}{c}\text { Részarány } \\
\mathbf{( \% )}\end{array}$ \\
\hline Algéria & 313,89 & 10,43 & 339,29 & 12,65 & 281,96 & 10,57 \\
\hline Azerbajdzsán & 601,30 & 19,98 & 769,90 & 28,72 & 881,58 & 33,05 \\
\hline Egyenlítői Guinea & 0 & 0 & 0 & 0 & 97,19 & 3,64 \\
\hline Irán & 499,82 & 16,61 & 543,13 & 20,26 & 0 & 0 \\
\hline Katar & 133,23 & 4,43 & 133,90 & 4,99 & 520,20 & 19,50 \\
\hline Nigéria & 107,52 & 3,57 & 0 & 0 & 85,35 & 3,20 \\
\hline Norvégia & 0 & 0 & 0 & 0 & 85,66 & 3,21 \\
\hline Oroszország & 1353,06 & 44,97 & 894,90 & 33,38 & 339,95 & 12,74 \\
\hline Trinidad és Tobago & 0 & 0 & 0 & 0 & 94,22 & 3,53 \\
\hline USA & 0 & 0 & 0 & 0 & 281,29 & 10,55 \\
\hline Összesen & 3008,82 & 100 & 2681,12 & 100 & 2667,41 & 100 \\
\hline
\end{tabular}

Forrás: T.C. Enerji Piyasası Düzenleme Kurumu: Doğal Gaz Piyasası Sektör Raporu Mayıs 2020. i. m. 6. és T.C. Enerji Piyasası Düzenleme Kurumu: Doğal Gaz Piyasası Sektör Raporu Mayıs 2018. [online], 2018. 7. Forrás: epdk.gov.tr [2020. 12. 16.]

3. táblázat: A vezetékes gáz és az LNG arányának alakulása Törökország földgázimportjában 2018-2020 májusa között

\begin{tabular}{|l|c|c|c|}
\hline & 2018. május & 2019. május & 2020. május \\
\hline Vezetékes gáz & $81,57 \%$ & $82,35 \%$ & $45,79 \%$ \\
\hline LNG & $18,43 \%$ & $17,65 \%$ & $54,21 \%$ \\
\hline
\end{tabular}

Forrás: T.C. Enerji Piyasası Düzenleme Kurumu: Doğal Gaz Piyasası Sektör Raporu Mayıs 2020. i. m. 5. és T.C. Enerji Piyasası Düzenleme Kurumu: Doğal Gaz Piyasası Sektör Raporu Mayıs 2018. [online], 2018. 6. Forrás: epdk.gov.tr [2020. 12. 16.] 
4. táblázat: Törökország földgázimportjának alakulása a 2020-as éven belül az egyes forrásországokból importált mennyiségek aránya szerint

\begin{tabular}{|l|r|r|r|r|r|r|r|r|r|}
\hline & $\begin{array}{c}\mathbf{2 0 2 0} \\
\text { január }\end{array}$ & $\begin{array}{c}\mathbf{2 0 2 0 .} \\
\text { február }\end{array}$ & $\begin{array}{c}\mathbf{2 0 2 0 .} \\
\text { március }\end{array}$ & $\begin{array}{c}\mathbf{2 0 2 0 .} \\
\text { április }\end{array}$ & $\begin{array}{c}\mathbf{2 0 2 0} \\
\text { május }\end{array}$ & $\begin{array}{c}\mathbf{2 0 2 0 .} \\
\text { június }\end{array}$ & $\begin{array}{c}\mathbf{2 0 2 0 .} \\
\text { július }\end{array}$ & $\begin{array}{c}\mathbf{2 0 2 0 .} \\
\text { augusztus }\end{array}$ & $\begin{array}{c}\mathbf{2 0 2 0} \\
\text { szeptember }\end{array}$ \\
\hline Algéria & $13,51 \%$ & $10,27 \%$ & $13,69 \%$ & $13,37 \%$ & $10,57 \%$ & $23,53 \%$ & $12,47 \%$ & $10,98 \%$ & $7,62 \%$ \\
\hline Azerbajdzsán & $15,78 \%$ & $16,34 \%$ & $23,45 \%$ & $34,80 \%$ & $33,05 \%$ & $46,09 \%$ & $35,17 \%$ & $29,40 \%$ & $20,23 \%$ \\
\hline Irán & $11,76 \%$ & $14,58 \%$ & $14,15 \%$ & $0 \%$ & $0 \%$ & $0 \%$ & $21,36 \%$ & $12,11 \%$ & $13,83 \%$ \\
\hline Katar & $5,85 \%$ & $12,78 \%$ & $19,95 \%$ & $9,94 \%$ & $19,50 \%$ & $13,16 \%$ & $0 \%$ & $3,96 \%$ & $3,47 \%$ \\
\hline Nigéria & $7,03 \%$ & $7,18 \%$ & $4,68 \%$ & $3,16 \%$ & $3,20 \%$ & $0 \%$ & $2,62 \%$ & $0 \%$ & $2,86 \%$ \\
\hline Oroszország & $36,90 \%$ & $21,14 \%$ & $9,89 \%$ & $17,86 \%$ & $12,74 \%$ & $7,86 \%$ & $27,11 \%$ & $40,84 \%$ & $49,85 \%$ \\
\hline USA & $3,21 \%$ & $17,71 \%$ & $9,38 \%$ & $10,95 \%$ & $10,55 \%$ & $4,89 \%$ & $0 \%$ & $2,70 \%$ & $2,13 \%$ \\
\hline Egyéb & $5,96 \%$ & $0 \%$ & $4,80 \%$ & $9,92 \%$ & $10,38 \%$ & $4,47 \%$ & $1,27 \%$ & $0 \%$ & $0 \%$ \\
\hline Összesen & $100 \%$ & $100 \%$ & $100 \%$ & $100 \%$ & $100 \%$ & $100 \%$ & $100 \%$ & $100 \%$ & $100 \%$ \\
\hline
\end{tabular}

Forrás: T.C. Enerji Piyasası Düzenleme Kurumu: Doğal Gaz Piyasası Sektör Raporu Ocak-Eylül 2020.

[online], 2020. Forrás: epdk.gov.tr [2020. 12. 16.]

Szükséges rávilágítani, hogy Törökország és partnerei között az energiadiplomáciai kapcsolatok hagyományosan jól müködtek és jól müködnek akkor is, ha a fennálló politikai természetű vitáik egyébként teherként nehezednek kapcsolataikra. A felek hozzáállása sok esetben tehát egy pragmatikus és a napi kapcsolatok volatilitása által csak korlátozott mértékben érintett energiapolitikai viszonyrendszerről tanúskodik, ami azt mutatja, hogy az energiaügyek stratégiai jelentősége a kompartmentalizáció jegyében arra ösztönzik a feleket, hogy azt kezeljék különálló egységként az egyéb politikai ügyektől. ${ }^{26}$ Hogy csak néhány példát említsünk: a Törökország és Oroszország közötti viszonylatban az energiakapcsolatokat nem érintették az orosz szankciók akkor sem, amikor 2015. november végén a török légierő a török-szír határ légterében lelötte az orosz hadsereg SZU-24-es típusú vadászbombázóját, és ezzel elhidegülés vette kezdetét a kétoldalú kapcsolatokban. ${ }^{27}$ Hasonlóképpen említhetjük Törökország LNG-vásárlásait Egyiptomtól, akivel politikai kapcsolatai évek óta mélyponton stagnálnak, vagy éppen az Egyesült Államoktól történő LNG-beszerzéseket, amit egy szintén összetett és sok szempontból konfrontatív bilaterális kapcsolat figyelembevételével szükséges értékelni.

\section{Régiós szerep: tranzitországból zavaró szomszéd?}

Törökország gázimportjának diverzifikációja révén és egyéb tényezőknek köszönhetően jelentős mértékben csökkent az egyoldalú függés, ami a külkapcsolatok alakításában nagyobb mozgásteret ad számára - főleg Moszkvával szemben. Az ország jelentősége azonban messze túlmutat a saját gázpiacán, hiszen az energiatranzit révén a nagy felvevőpiac-

26 Ziya Öniş - Şuhnaz Yilmaz: Turkey and Russia in a shifting global order: cooperation, conflict, and asymmetric interdependence in a turbulent region. Third World Quarterly, 37. (2016), 1. 71-95.

27 Pénzváltó Nikolett: Orosz-török energiapolitikai kapcsolatok 2019 tavaszán: a folyamatban lévő stratégiai energiaprojektek értékelése. Nemzet és Biztonság, (2019), 2. 31-49. 
nak számító Európai Unió (vagy legalábbis annak több országa) és a jelentős készletekkel rendelkező Kaukázus és Közel-Kelet között helyezkedik el. ${ }^{28}$

Ebből kifolyólag az Európai Unió számára Törökország részvétele nemzetközi energiaprojektekben - de különösképpen a Déli Gázfolyosó projekt megvalósításában - fontos hozzájárulást jelent az EU földgázellátásának diverzifikációjához, hiszen a projekt lehetővé teszi, hogy uniós tagállamok Kaszpi-tengeri eredetű földgázt vásároljanak Azerbajdzsántól a Törökországot is érintő infrastruktúrán keresztül. Hozzá kell tenni továbbá, hogy Törökország potenciálisan útvonala lehet további forrásokból származó - az orosszal szemben alternatívát jelentő - gázmennyiségeknek is, amelyek az uniós piacokat célozhatják. Egyfelöl tehát látható és nyomon követhető az az uniós érdek, amely Törökország geostratégiai fekvésére alapozva igyekezett a 2000-es és 2010-es években egy pozitív energiaagendát fenntartani Törökországgal, és ez egybeesett Törökország célkitűzésével is, amely a regionális energiabiztonsági architektúrában betöltött szerepének fejlesztésére irányul. Az ország korábban tapasztalt felértékelődése azonban a gáz uniós megítélésének változásával csökken. Másfelől viszont a Földközi-tenger keleti medencéjében, Törökország és Görögország, valamint Törökország és Ciprus között, éppen a tenger alatti földgázlelöhelyek utáni kutatások körül kialakult feszültségek megszaporodása látszik változást hozni abba a tendenciába, miszerint Törökország alapvetően le tudta választani a sok szempontból egyre konfliktusosabbá váló külkapcsolatairól az energiapolitikai ügyeket. Sőt, 2020 nyarára/őszére éppen a Kelet-Mediterráneumban zajló, energiapolitikai kiindulóponttal rendelkező, ámde számos más dimenziót is magáénak tudható konfliktus vált az Európai Unió és Törökország közötti napirendet aktuálisan leginkább terhelö üggyé.

Mindemellett megemlítendők az Európai Uniónak az európai zöldmegállapodás jegyében megfogalmazott célkitüzései, amelynek értelmében azt kívánják elérni, hogy 2050-re klímasemlegessé váljanak az uniós országok, az üvegházhatásúgáz-kibocsátás szintje pedig nettó nullára csökkenjen az uniós gazdaságokban. ${ }^{29} \mathrm{Ez}$ a törekvés elörevetíti a fosszilis energiahordozóktól való elfordulást, amit természetesen egy hosszadalmas folyamatként szükséges értelmezni, azonban már most elkezdődött. Az Európai Unió szempontjából így csökken a földgázalapú együttmüködések fontossága, és ezzel együtt azon projektek relevanciája, amelyek az unióba irányuló földgázszállításokat célozzák. Ezt a tendenciát figyelembe kell vennie többek között Törökországnak is, mivel uniós szempontból kiemelkedően fontos energiatranzit-országként Törökország energiahíd-szerepe hosszú távon így vélhetően veszíthet jelentőségéből. Éppen ezért is fontos Ankara számára, hogy addig is haszonmaximalizáló politikát folytasson ebben a viszonylatban, és rövid és középtávú geopolitikai és gazdasági előnyökre tegyen szert.

A Földközi-tenger keleti-medencéjében 2010-es évek elejétől napjainkig tartó gázfeltárásai újrarajzolták a Törökország körüli gázlelőhelyek térképét. Míg a 2000-es évek során szinte egyértelmű volt, hogy amennyiben a közel-keleti térségből vagy a Kaukázusból gázexport indul Európába (az LNG akkori drágasága és a megfelelő infrastruktúra hiánya

28 Egeresi Zoltán: Törökországnak a regionális energiaelosztó szerepre irányuló törekvései. Külügyi Szemle, 17. (2018), 3. $73-98$.

29 A témáról bővebben lásd: Európai Tanács - Európai Unió Tanácsa: Európai zöld megállapodás. [online], Forrás: consilium.europa.eu [2020. 12. 16.] 
miatt), akkor ez elsősorban vezetéken, és ebben az esetben Törökországon keresztül fog történni. Ezt volt hivatva anno a Nabucco elérni (feltételezett iraki és iráni gázszállítással). Végül ez nem valósult meg, azonban így is történtek előrelépések: megépült két gázvezeték Azerbajdzsánból, az utolsó, a TANAP deklarált céllal azért, hogy európai piacokra is jusson a Kaszpi-tenger mellékén kitermelt gázból. A török politika, amely azt tüzte ki, hogy az ország regionális energiaelosztóvá váljon, ezen a területen tehát jelentős sikereket ért el.

Ugyanakkor a földközi-tengeri feltárások (5. táblázat) jelentős változást hoztak az ország közvetlen szomszédságában. Mivel ezek a gázmezők jellemzően Ciprus-Izrael-Egyiptom határvidékén találhatóak, így európai piacokra való juttatásukban ugyan Törökország is szerepet kaphatott volna, esetleges vezetékek építése révén, azonban a mediterrán országok, amelyekkel amúgy is megromlott Ankara kapcsolata legkésőbb 2013-ra (Ciprussal pedig korábban sem volt jó, tekintve, hogy a görög ciprióta államalakulatot nem ismeri el Törökország), ettől elzárkóztak.

\section{5. táblázat: A legjelentősebb offshore földgázmezök a Kelet-Mediterrán térségben}

\begin{tabular}{|l|c|c|c|}
\hline \multicolumn{1}{|c|}{ Gázmezö neve } & Ország & Felfedezés éve & Talált gázmennyiség becsült volumene \\
\hline Aphrodite & Ciprus & 2011 & $129 \mathrm{bcm}$ \\
\hline Calypso & Ciprus & 2018 & $170-230 \mathrm{bcm}$ \\
\hline Glaucus & Ciprus & 2019 & $142-227 \mathrm{bcm}$ \\
\hline Zohr & Egyiptom & 2015 & $850 \mathrm{bcm}$ \\
\hline Leviathan & Izrael & 2010 & $605 \mathrm{bcm}$ \\
\hline Tamar + Tamar SW & Izrael & 2009 & $318 \mathrm{bcm}$ \\
\hline
\end{tabular}

Forrás: Kozma Tamás: Turkey and the geopolitics of natural gas in the Eastern Mediterranean. [online], 2020. 04. 13. Forrás: trendsresearch.org [2020. 12. 16. $]^{30}$

A ciprusi kérdés rendezetlensége miatt ${ }^{31}$ a szigettől délre végzett feltárások azonnal vitához vezettek, amelyek során a török fél arra hivatkozott, hogy a gázmezőkből származó (jövőbeli) jövedelemböl a ciprusi törököknek is részesedniük kell, míg ezzel szemben a görögök úgy látják, hogy amíg nincs rendezés, addig az északon élőknek ebből nem jár semmi. ${ }^{32}$ A viták az utóbbi tíz évben hasonló forgatókönyvet követtek: egy-egy ciprusi lépésre (feltárásra, megállapodásra, akár nemzetközi cégekkel, akár a szomszédos államokkal) a törökök igyekeztek hasonló válaszokat adni, és demonstratíve kutatóhajókat, akár hadihajókkal megtámogatva küldtek a ciprusi, újabban görög vizekre.

30 A táblázatban csak a 100 bcm-et meghaladó méretű gázmezőket soroltuk fel. A felsoroltakon kívül még számos kisebb méretü gázmezőt fedeztek fel a térségben.

31 Törökország 1974-ben foglalta el a sziget északi részét, ahol 1983-ban kikiáltották az egyedül Ankara által elismert Észak-Ciprusi Török Köztársaságot. Nemzetközi szinten a déli, görögök lakta terület maradt Ciprusi Köztársaság, amelyet Törökország nem ismer el államalakulatként, hanem helyette Dél-ciprusi Görög Adminisztrációnak nevez (Güney Kıbrıs Rum Yönetimi - GKRM). A többszöri, ENSZ által menedzselt béketárgyalások nem vezettek sikerre, az Annan-terv szerinti, 2004-es népszavazáson pedig a görög ciprióta fél utasította el a sziget újraegyesítésének lehetöségét. Mivel a kialakult helyzetet máig nem rendezték, így ez mind Törökország uniós csatlakozására, mind energetikai törekvéseire nézve problémát jelent. Erről lásd részletesebben: Kacziba Péter: Többség kisebbségi, kisebbség többségi támogatással: Az anyaországi beavatkozás szerepe Cipruson. In Szalai Máté - Wagner Péter (szerk.): A többség-kisebbség dinamika szerepe a közel-keleti konfliktusokban. Budapest, Külügyi és Külgazdasági Intézet, 2019. 58-80.

32 Kacziba Péter: A ciprusi földgázkincs feltárásának bel- és külpolitikai sajátosságai. Külügyi Szemle, 12. (2013), 4. 149171. 
Az első sikeres ciprusi feltárások után Törökország delimitációs egyezményt írt alá az Észak-ciprusi Török Köztársasággal, illetve kijelölték annak tengeri határait is - jelentős területen átfedést hozva létre a ciprusi görögök által magukénak tartott vizekkel. Így már a 2011-től folyamatosan napirenden lévő határvitát és a nemzetközi kedélyeket az újabb és újabb felfedezések után a vitatott térségbe küldött kutató- és hadihajók zavarták.

Nicosia részben üzleti, részben külpolitikai megfontolásokból a hozzá tartozó területet blokkokba osztva különböző cégekkel állapodott meg a feltárásokról és a kitermelésről. Így érdekelt lett az ENI (Olaszország), a Total (Franciaország), az ExxonMobil and Noble Energy (Egyesült Államok), ezzel rögtön számos hatalmat érdekeltté téve a konfliktusban. A közös érdekek miatt ráadásul hamarosan kialakult egy görög-izraeli-ciprusi, illetve görög-ciprusi-egyiptomi együttmüködési mechanizmus, valamint 2019 elején megalakult a Kelet-Mediterrán Gáz Fórum, Törökország és az Észak-ciprusi Török Köztársaság teljes mellőzésével.

Ankara tehát kimaradt a határaitól délre kötött energetikai megállapodásokból, ami nemcsak az ország energiaelosztó szerepét gyengítette, de a vitás kérdéseket is nyitva hagyta. ${ }^{33}$ Ebben a helyzetben Törökország úgy döntött, hogy az elszigeteltségéből a líbiai egységkormánnyal (GNA) kötött megállapodással fog kitörni. Így 2019. november végén két memorandumot is aláírtak, egyiket a török katonai segítségnyújtásról, másikat pedig a közös tengeri határról: ez utóbbi eredményeképp a görög és ciprusi vizeteket kettévágva jött létre a határ. ${ }^{34} \mathrm{Az}$ egyoldalú akció komoly kritikát váltott ki a régióban, mivel ez szembement az Egyesült Nemzetek Tengerjogi Egyezményével (UNCLOS), amelyet Görögország, Ciprus és Egyiptom aláírtak, Törökország viszont nem.

Miután a török és a szíriai zsoldos csapatok megjelentek 2020 legelején Líbiában, és a következő hónapokban nemcsak megvédték Tripolit Haftar tábornok csapataitól, de egészen Szirtig nyomultak előre, újrarajzolták a líbiai erőviszonyokat. Ezzel egyúttal biztosították a novemberben a memorandumban foglaltakat, mivel azokat - így a közös tengeri határvonalat - Haftar semmisnek tekintette. A továbbnyomulásnak végül Kairó jelzése ${ }^{35}$ vetett véget. Ezzel együtt Törökország komoly pozíciókra tett szert az ország energiahordozókban szintén gazdag nyugati részén. Mivel ezen a területen található az ENI líbiai érdekeltségeinek döntő része, így Rómának is kooperálnia kell Ankarával.

Ugyan egyelöre Líbia még nem jelent meg komolyabb energiahordozóként Törökország partnerei között, ahogy Kaddáfi alatt is nagyobb infrastrukturális projektekben részt vehettek török cégek, ${ }^{36}$ úgy a polgárháborút követő újjáépítésben a remények szerint komoly szerepet játszhatnak, és a későbbiekben egy törökbarát Líbia megbízható beszállítóvá válhat.

33 Az energetikai megfontolásokon túl a vita - hozzákapcsolva a több évtizedes ciprusi kérdéshez - a török belpolitikában is megjelenik. A földközi-tengeri török hatalmi törekvéseket kifejező nacionalista „Kék haza” (Mavi vatan) koncepció ezt hivatott legitimálni: a felségvizeket a kontinentális talapzat és nem a szigetek alapján figyelembe vevő megközelítés jóval nagyobb területet juttatna az országnak, amely a „legnagyobb tengerparttal rendelkezik a Kelet-Mediterráneumban”, így tehát egy-két kisebb görög sziget nem zárhatja be az országot az Antalya és Adana melléki vizekre.

34 Mesut Hakki Casin: Analysis - Strategic, legal aspects of Turkey-Libya deal. [online], 2019. 12. 13. Forrás: aa.com.tr [2020. 12. 20.]

35 Aydogan Kalabalik: Egypt: Parliament authorizes army to intervene in Libya. [online], 2020. 07. 20. Forrás: aa.com.tr [2020. 12. 20.]

36 Kacziba Péter: A líbiai polgárháború szerepe a görög-török konfliktus elmélyülésében. Pólusok, 1. (2020), 1. 47-82. 
Törökország a kelet-mediterráneumi beavatkozásával megkérdőjelezte a status quót, ami szorosabb együttmüködésre késztette a régióban érdekelt hatalmakat. Ennek látványos jele a 2020 augusztusában megkötött görög-egyiptomi tengeri delimitációs szerzödés, amely teljesen felülírta a török-líbiai megállapodást. ${ }^{37}$ Erre Ankara hadihajók küldésével válaszolt a vitatott görög felségvizekre, folytatván az évek óta tartó eszkalációs spirált. A „hagyományos” görög-török határvitákhoz képest a jelenlegi mind méretében, mind súlyában nagyobb: a különböző hatalmak érintettsége miatt ez komoly nemzetközi kérdésként merül fel, és az Európai Unió is ellenlépéseket tett. Ráadásul a közösségen belül a francia-görög-ciprusi vezetők igyekeznek komolyabb szankciók kivetésére rávenni az Európai Tanácsot, ami alapvetően Németország kompromisszumkereső álláspontja, illetve néhány tagállam ellenkezése miatt nem valósult meg. ${ }^{38}$ Míg tehát egyrészről a szárazföldi vezetékek kiépítésével Törökország hozzájárul az unió energiabiztonsági céljainak eléréséhez, addig a földközi-tengeri beavatkozásával inkább rontja annak lehetőségeit, azzal, hogy uniós tagállamok nemzetközi jogilag rögzített tengeri határait kérdőjelezi meg.

\section{Konklúzió}

Törökország gázpiaca az utóbbi években jelentős mértékben átalakult. Az energiamixének közel harmadát adó földgázban szegény ország a tárolókapacitások és az importpartnerek körének bővítésével jelentős mértékben javította energiabiztonságát, illetve erősítette régiós energiaelosztó szerepét.

Míg korábban Oroszország számított a legfontosabb beszállítónak, az import akár 50-60\%-át adva, addig a részesedése 2019-2020-ban jelentős mértékben visszaesett, mintegy 30\%-ra. A változás oka a tudatos török diverzifikációs politika és infrastrukturális beruházások mellett a gázpiac jelentős átalakulása, flexibilisebbé válása volt. A sokkal olcsóbbá váló LNG-nek köszönhetően a vezetékes szállítások aránya 2020 tavaszára lecsökkent 50\% alá, miközben az Azerbajdzsánból érkező gáz aránya dinamikusan nőtt az orosz kárára az importon belül. A 2020-as adatokra erősen rányomja bélyegét a pandémia, azonban ez a tendencia már korábban megkezdődött. A közeljövőben ezen a téren nem várható változás, ráadásul a 2020 nyár végén bejelentett fekete-tengeri gázmezők kitermelése pedig a török importfüggőséget hosszabb távon csökkenteni fogja. Azonban fontos hangsúlyozni, hogy Ankara célja nem az oroszokkal való szakítás, hanem a gázdiverzifikáció révén az energiabiztonság, illetve nagyobb fokú függetlenség elérése, ami a gázárakban is jelentkezhet. Amennyiben Moszkva képes lesz állni az LNG jelentette versenyt, úgy akár még nőhet is az aránya a török gázimportban, noha nem várható, hogy $50 \%$ fölé kúszna.

A Transzanatóliai és a Török Áramlat gázvezetékek átadásával (2019, illetve 2020) pedig a tranzitszerepét erősítette meg. Míg tehát Ankara ezen a téren növelte hozzájárulását az európai gázdiverzifikációs törekvésekben, addig kelet-mediterráneumi beavatkozása pontosan azt nehezíti, különösen Ciprus viszonylatában. A török felségvizek kiterjesztése,

37 Reuters: Egypt and Greece sign agreement on exclusive economic zone. [online], 2020. 08. 06. Forrás: reuters.com [2020. 12. 20.]

38 Sarantis Michalopoulos: Merkel and Borissov blocked EU sanctions against Turkey at summit: sources. [online], 2020. 12. 11. Forrás: euractiv.com [2020. 12. 20.] 
a közös líbiai-török tengeri határ egyoldalú bejelentése és hadihajók felvonultatása egyértelmü jelzése annak, hogy Ankara nem akar kimaradni a régiós gázüzletből, azonban egyelőre a régiós szövetségek megerősödése, korlátozott uniós szankciók és néhány kutatóhajó eltántorításán ${ }^{39}$ kívül nem sikerült eredményt felmutatni. Ugyanakkor azt sem érdemes figyelmen kívül hagyni, hogy nemcsak a gázmezők játszanak szerepet ebben a kérdésben, hanem egyéb stratégiai és belpolitikai megfontolások is.

A török blokkolás kevésbé látványos a jelenlegi viszonyok között: mivel egyelöre a kiterjesztett török vizeken nem sikerült gázt találniuk a kutatóhajóknak, és a jelenlegi gázárak mellett sem a mélyen lévő gázmezők kitermelése, sem a Kelet-Mediterrán gázvezeték megépítése nem éri meg. Ez azonban változhat, különösen akkor, ha értelmezhető mennyiségü gázt találnak a vitatott területeken: ebben az esetben vagy egy Törökországgal kötött megegyezés keretében rendezik a kérdést, és Ankarát beengedik a gázüzletbe, vagy pedig nagy valószínűséggel hosszú távon ellehetetlenül azoknak a mezőknek a kitermelése.

\section{FELHASZNÁLT IRODALOM}

Adar, Sinem - Ilke Toygür: Turkey, the EU and the Eastern Mediterranean Crisis: Militarization of Foreign Policy and Power Rivalry. [online], Stiftung Wissenschaft und Politik Comment, (2020), 62. 1-4. Forrás: swp-berlin. org [2020. 12. 16.] DOI: https://doi.org/10.18449/2020C62

ANSA: ENI ship blocked off Cyprus leaves (3). [online], 2018. 02. 23. Forrás: ansa.it [2020. 12. 20.]

Casin, Mesut Hakki: Analysis - Strategic, legal aspects of Turkey-Libya deal. [online], 2019. 12. 13. Forrás: aa.com. $\operatorname{tr}[2020.12 .20$.

Cheasty, Adrienne: Black Sea gas: Economic and geopolitical implications. [online], 2020. 11. 16. Forrás: seesoxblog. blogspot.com [2020. 12. 16.]

Climate Transparency: Brown to Green: The G20 Transition Towards a Net-Zero Emissions Economy. [online], 2019. Forrás: climate-transparency.org [2020. 12. 16.]

Deák András György: Alternatíva, potyautas vagy hajótörött - a földgáz esélyei Délkelet-Európában. [online], Stratégiai Védelmi Kutatóintézet Elemzések, (2020), 26. 1-15. Forrás: mhtt.eu [2020. 12. 16.]

Egeresi Zoltán: Törökországnak a regionális energiaelosztó szerepre irányuló törekvései. Külügyi Szemle, 17. (2018), 3. 73-98.

Egeresi Zoltán - Kacziba Péter: Menekültválság a görög-török határon: Előzmények, fejlemények, kilátások. [online], KKI Elemzések, (2020), 25. Forrás: kki.hu [2020. 12. 14.]

Euractiv: Turkey, Russia launch Turkish Stream pipeline carrying gas to Europe. [online], 2020. 01. 09. Forrás: euractive.com [2020. 12. 16.]

Európai Tanács - Európai Unió Tanácsa: Európai zöld megállapodás. [online], Forrás: consilium.europa.eu [2020. 12. 16.]

Eqbali, Aresu - David O’Byrne: Iran expects gas flows to Turkey to resume in July, rejects force majeure claim. [online], 2020. 07. 08. Forrás: spglobal.com [2020. 12.16.]

Hürriyet Daily News: Turkey to expand LNG storage capacity with 3rd FSRU. [online], 2020. 10. 09. Forrás: hurriyetdailynews.com [2020. 12. 16.]

Hürriyet Daily News: Turkey wins gas price row against Iran in court. [online], 2016. 02. 02. Forrás: hurriyetdailynews.com [2020. 12. 16.]

Kacziba Péter: A ciprusi földgázkincs feltárásának bel- és külpolitikai sajátosságai. Külügyi Szemle, 12. (2013), 4. 149-171.

39 ANSA: ENI ship blocked off Cyprus leaves (3). [online] 2018. 02. 23. Forrás: ansa.it [2020. 12. 20.] 
Kacziba Péter: Többség kisebbségi, kisebbség többségi támogatással: Az anyaországi beavatkozás szerepe Cipruson. In Szalai Máté - Wagner Péter (szerk.): A többség-kisebbség dinamika szerepe a közel-keleti konfliktusokban. Budapest, Külügyi és Külgazdasági Intézet, 2019. 58-80.

Kacziba Péter: A líbiai polgárháború szerepe a görög-török konfliktus elmélyülésében. Pólusok, 1. (2020), 1. 47-82. DOI: https://doi.org/10.15170/PSK.2020.01.01.03

Kacziba Péter: Törökország Fekete-tengeri gázfeltárásai - Lehetőségek, korlátok és regionális vonatkozások. Pólusok, 1. (2020), 1. 176-192. DOI: https://doi.org/10.15170/PSK.2020.01.01.09

Kalabalik, Aydogan: Egypt: Parliament authorizes army to intervene in Libya. [online], 2020. 07. 20. Forrás: aa.com.tr [2020. 12. 20.]

Korteweg, Rem: Energy as a tool of foreign policy of authoritarian states, in particular Russia. [online], 2018. Forrás: European Parliament [2020. 12. 17.] DOI: https://doi.org/10.2861/951739

Kozma Tamás: Turkey and the geopolitics of naturalgas in the Eastern Mediterranean. [online], 2020. 04. 13. Forrás: trendsresearch.org [2020. 12. 16.]

Michalopoulos, Sarantis: Merkel and Borissov blocked EU sanctions against Turkey at summit: sources. [online] 2020. 12. 11. Forrás: euractiv.com [2020. 12. 20.]

O’Byrne, David: Turkish President Erdogan announces 320 Bcm Black Seagas discovery. [online], 2020. 08. 21. Forrás: spglobal.com [2020. 12. 16.]

O’Byrne, David: Turkey increases size of Black Sea gas find by 85 Bcm to 405 Bcm [online], 2020. 10. 17. Forrás: spglobal.com [2020. 12. 16.]

Organization of the Petroleum Exporting Countries: Annual Statistical Bulletin. [online], 2020. Forrás: opec. org [2020. 12. 16.]

The Oxford Institute for Energy Studies: Analysis of cross-border flows in SE Europe. [online], 2020. 12. Forrás: oxfordenergy.org [2020. 12. 16.]

Öniş, Ziya - Şuhnaz Yilmaz: Turkey and Russia in a shifting global order: cooperation, conflict, and asymmetric interdependence in a turbulent region. Third World Quarterly, 37. (2016), 1. 71-95. DOI: https://doi.org/1 0.1080/01436597.2015.1086638

Pénzváltó Nikolett: Orosz-török energiapolitikai kapcsolatok 2019 tavaszán: a folyamatban lévő stratégiai energiaprojektek értékelése. Nemzet és Biztonság, (2019), 2. 31-49. DOI: https://doi.org/10.32576/nb.2019.2.4

Reuters: Egypt and Greece sign agreement on exclusive economic zone. [online], 2020. 08. 06. Forrás: reuters. com [2020. 12. 20.]

Rzayeva, Gulmira: The Renewal of Turkey's Long Term Contracts: Natural gas market transitionor 'business asusual'? [online], 2020. 09. Forrás: oxfordenergy.org [2020.12. 16.]

T.C. Enerji Piyasası Düzenleme Kurumu: Doğal Gaz Piyasası 2017-2018-2019 Yılı Sektör Raporu. [online]. Forrás: epdk.gov.tr [2020. 12.16.]

T.C. Enerji Piyasası Düzenleme Kurumu: Doğal Gaz Piyasası 2019 Yilı Sektör Raporu. [online], 2020. 10. Forrás: epdk.gov.tr [2020. 12. 16.]

T.C. Enerji Piyasası Düzenleme Kurumu: Doğal Gaz Piyasası Sektör Raporu Mayıs 2018. [online], 2018. Forrás: epdk.gov.tr [2020. 12. 16.]

T.C. Enerji Piyasası Düzenleme Kurumu: Doğal Gaz Piyasası Sektör Raporu Mayıs 2020. [online], 2020. Forrás: [2020. 12. 16.]

T.C. Enerji Piyasası Düzenleme Kurumu: Doğal Gaz Piyasası Sektör Raporu Ocak-Eylül 2020. [online], 2020. Forrás: epdk.gov.tr [2020. 12. 16.]

The World Bank: Turkey - Dataset. [online], 2020. Forrás: data.worldbank.org [2020. 12. 16.] 